\title{
ANALISIS PEMAHAMAN PENDERITA TB TENTANG TUBERKULOSIS PARU TERHADAP KUALITAS HIDUP
}

\author{
Dedi Pahrul $^{1}$, Helsy Desvitasari ${ }^{2}$, Asih Fatriansari $^{3}$ \\ Program Studi Ilmu Keperawatan STIK Siti Khadijah Palembang \\ Email: depha86@yahoo.co.id
}

\begin{abstract}
ABSTRAK
Latar Belakang :Tuberkulosis paru merupakan penyakit yang menular secara langsung yang berasal dari kuman Mycobacterium tuberculosis. Tujuan penelitian:Mengetahui hubungan tingkat pengetahuan tentang tuberkulosis dengan kualitas hidup pasien tuberkulosis di rumah sakit khusus paru provinsi sumatera selatan. Metode penelitian: Menggunakan Descriptive Analitik dengan pendekatan cross sectional. Pengambilan sampel dengan cara Accidental sampling dengan jumlah sampel sebanyak 31 responden. Hasil Penelitian :Ada hubungan pengetahuan tentang tuberkulosis paru dengan kualitas hidup pasien tuberkulosis paru di Rumah Sakit Khusus Paru Provinsi Sumatera Selatan, didapatkan $p$ value $=0,000 \leq \alpha=0.05$ sehingga H0 ditolak dan Ha diterima. Simpulan : Bahwa kualitas hidup pada penderita tuberculosis dipengaruhi oleh tingkat pengetahuan yang dimiliki, karena dengan pengetahuan yang baik membuat penderita memahami tentang kesehatan dan mengikuti program pengobatan sehingga membuat keadaan penderita diharapkan menjadi lebih baik dan tidak merasa tanda dan gejala penyakit sehingga memperbaiki keadaan fisik dan psikis penderita, semakin tingginya tingkat pengetahuan penderita maka semakin baik pula kualitas hidup penderita.
\end{abstract}

\section{Kata Kunci : Tuberkulosis, Tingkat Pengetahuan, Kualitas Hidup}

\begin{abstract}
Background:Pulmonary tuberculosis is a contagious disease that originates directly from the Mycobacterium tuberculosis bacteria. Aims: of this study was to know the relationship of the level of knowledge about tuberculosis with the quality of life of tuberculosis patients in lung hospitals in South Sumatra province. Method :The design of this study uses Descriptive Analytic with cross sectional approach. Sampling by accidental sampling with a total sample of 31 respondents. Result : Obtained there is a relationship of knowledge about pulmonary tuberculosis with the quality of life of pulmonary tuberculosis patients in the Lung Hospital of South Sumatra Province, obtained p value $=0.000 \leq \alpha=0.05$, so H0 is rejected and Ha is accepted. Conclusion :So it can be analyzed that the quality of life in patients with tuberculosis is influenced by the level of knowledge possessed, because with good knowledge makes patients understand about health and follow treatment programs so as to make the patient's condition expected to be better and not feel signs and symptoms of the disease so that it improves physical condition and psychic sufferers, the higher the level of patient knowledge, the better the quality of life of sufferers.
\end{abstract}

Key Words : Tuberculosis, Knowledge Level, Life Quality 


\section{PENDAHULUAN}

Tuberkulosis Paru merupakan penyakit yang menular secara langsung yang berasal dari kuman Mycobacterium tuberculosis dengan cara penularan melalui batuk yang mengeluarkan partikel - partikel air liur yang menyerang terutama pada paru-paru dan juga menyerang organ-organ lain (Kemenkes RI, 2013).

World Health Organization (WHO) pada tahun 2015 menjadikan Tuberkulosis sebagai penyakit yang menular pembunuh terbesar di dunia.Menurut WHO tahun 2017, di tahun 2017 diperkirakan ada 1.020.000 kasus Tuberkulosis Paru di Indonesia, namun terlapor ke Kementerian Kesehatan sebanyak 420.000 kasus. Jumlah tersebut mengalahkan Tiongkok di urutan ketiga yang memiliki sekitar 1,4 milyar penduduk. Hanya satu negara yang lebih buruk jumlah kasus tuberkulosis parunya dari Indonesia, yakni India yang memiliki jumlah penduduk 1,3 milyar.

Berdasarkan data hasil evaluasi program Pemberantasan Penyakit Tuberkulosis Paru (P2TB) Dinas Kesehatan Provinsi Sumatera Selatan pada tahun 2013 -2015. Jumlah suspek tahun 2013 sebanyak 33.589 orang, BTA Positif 4.714 orang, BTA negatif rontgen positif 2.170 orang, kemudian terjadi peningkatan pada tahun 2014, yakni jumlah suspek tahun 2014 sebanyak 39.339 orang, BTA Positif 5.259 orang, BTA negatif rontgen positif 2.363 orang dan angka Drop Out (DO) sebanyak 47 orang. Selanjutnya pada tahun 2015, jumlah suspek tahun 2015 sebanyak 37.940 orang, BTA positif 5.022 orang, BTA negatif rontgen positif 2.630 orang. (Dinkesprov sumsel, 2015)

Berdasarkan data yang diperoleh data dari Dinas Kesehatan Kota Palembang menyatakan jumlah penderita masih berada pada kisaran puluhan ribu orang, di tahun 2013 jumlah penderita Tuberkulosis paru mencapai 1.474 orang, sedangkan 2014 mengalami peningkatan jumlah penderita tuberkulosis paru mencapai 1.972 orang, tahun 2015 jumlah penderita tuberkulosis paru mencapai 1.305, tahun 2016 jumlah penderita TB paru mencapai 1.312 orang, tahun 2017 jumlah penderita tuberkulosis paru mencapai 2.618 (Dinkes Kota Palembang, 2017)

Data di Rumah Sakit Khusus Paru Provinsi Sumatera Selatan pada tahun 2016 tercatat 315 kasus tuberkulosis paru. Pada tahun 2017 mengalami peningkatan jumlah kasus yaitu tercatat 388 kasus tuberkulosis paru, sedangkan pada tahun 2018 tercatat 376 kasus tuberkulosis paru. (Medical Record Rumah Sakit Khusus Paru Provinsi Sumatera Selatan, 2018).

Jumlah penderita tuberkulosis paru yang masih tinggi di Indonesia, menjadi tugas bagi pemerintah dan petugas kesehatan untuk menanggulangi bertambahnya penderita tuberkulosis yang juga harus didukung dari kesadaran masyarakat untuk menjaga kesehatan. Menderita tuberkulosis paru menimbulkan berbagai perubahan yang terjadi pada penderita baik mental, fisik maupan sosial, seperti penurunan berat badan, batuk, sesak nafas dan lemah yang mempengaruhi kehidupan sehari - hari penderita (Wijaya, 2013).

Perubahan tersebut berpengaruh pada pandangan penderita terhadap dirinya sendiri dan juga pandangan orang lain terhadap keadaan penderita sehingga dapat mempengaruhi kualitas hidup penderita. Kualitas hidup merupakan pandangan persepsi diri terhadap nilai kehidupan dan rasa kepuasan terhadap kehidupan yang mereka jalani (Sarafino, 2011).

Salah satu upaya dalam meningkatkan kualitas hidup penderita tuberkulosis paru adalah dengan pemberian informasi atau pengetahuan mengenai proses penyembuhan tuberkulosis paru. Penelitian yang dilakukan oleh Miranti (2012) menyatakan umur, olahraga, waktu tidur, pengetahuan, kepatuhan berobat, dukungan keluarga, diet merupakan suatu ikatan yang mempengaruhi keadaan status kualitas hidup seseorang.

Pengetahuan merupakan informasi yang di ketahui seseorang dengan 
pengindraan terhadap objek tertentu. Kurang pengetahuan pasien terhadap penyakit dan penggunaan obat untuk terapi mengakibatkan ketidakpahaman pasien terhadap terapi yang dijalani sehingga menyebabkan ketidak patuhan pasien dalam mengkonsumsi obatnya (GonzalezBarcalana, $d k k ., 2012)$.

Hasil wawancara peneliti dengan perawat yang menangani penyakit $\mathrm{TB}$ di Rumah Sakit Khusus Paru Provinsi Sumatera Selatan. Dari kasus di Rumah Sakit Khusus Paru Provinsi Sumatera Selatan didapatkan data hasil wawancara pertanyaan umum tentang tuberkulosis paru bahwa penderita tuberculosis yang belum memahami secara detail tentang tingkat pengetahuan tuberkulosis paru. Pada saat wawancara dengan pasien sebanyak 5 orang dan sebanyak 4 orang mengatakan bahwa dirinya malu untuk bersosialisasi dengan warga lain karena penyakit yang dideritanya. Fenomena ini menggambarkan bahwa masih banyak masyarakat yang tidak mengerti atau tidak tahu tentang tuberkulosis paru dan kesejahteraan psikologis yang masih mengganggu dirinya. Kurangnya pengetahuan tentang tuberkulosis paru mengakibatkan penderita terlambat mencari pengobatan atau bahkan tidak berobat sama sekali. Hal ini membuat peneliti tertarik mengambil judul tentang Hubungan Pengetahuan Tentang Tuberkulosis Paru Dengan Kualitas Hidup Pasien Tuberkulosis Paru di Rumah Sakit Khusus Paru Provinsi Sumatera Selatan.

\section{METODE PENELITIAN}

Rancangan penelitian ini menggunakan Descriptive Analitik dengan pendekatan cross sectional untuk melihat hubungan antara tingkat pengetahuan tentang tuberkulosis dengan kualitas hidup pasien tuberkulosis paru di Rumah Sakit Khusus Paru Provinsi Sumatera Selatan.

Populasi dalam penelitian ini adalah semua pasien TB paru di Rumah Sakit Khusus Paru Provinsi Sumatera Selatan pada bulan Januari - April 2019 dengan jumlah populasi 102 pasien. Dalam pengambilan ini digunakan teknik pengambilansampel menggunakan Accidental Sampling yaitu 31 responden.

Penelitian ini telah dilakukan di Poliklinik Rumah Sakit Khusus Paru Provinsi Sumatera Selatan pada tanggal 23 Juli 2019 - 5 Agustus 2019. Untuk mengetahui hubungan pengetahuan tentang tuberculosis paru dengan kualitas hidup penderita tuberculosis paru di Rumah Sakit Khusus Paru Provinsi Sumatera Selatan, mengunakan uji Chi-Square dengan $\alpha=$ 0,05 .

\section{HASIL PENELITIAN}

Analisis Univariat

a.Frekuensi Responden Berdasarkan Tingkat Pengetahuan

Tabel 1

Distribusi Frekuensi Responden Pengetahuan Tentang Tuberkulosis Paru Pada Pasien Tuberkulosis Paru Di Rumah Sakit Paru Provinsi Sumatera Selatan

\begin{tabular}{lcc}
\hline Pengetahuan & $\begin{array}{c}\text { Frekuensi } \\
(\mathbf{n})\end{array}$ & $\begin{array}{c}\text { Persentase } \\
(\boldsymbol{\%})\end{array}$ \\
\hline Baik & & \\
Kurang & 14 & 45,2 \\
\hline \multicolumn{1}{c}{ Total } & 17 & 54,8 \\
\hline
\end{tabular}

Bedasarkan tabel 1 diatas dapat diperoleh hasil bahwa responden Tingkat pengetahuan baik sebanyak 14 orang (45,2 $\%)<$ dibandingkan dengan responden yang memiliki tingkat pengetahuan kurang sebanyak 17 orang $(54,8 \%)$.

\section{b.Frekuensi responden berdasarkan kualitas hidup}

Tabel 2

Distribusi Frekuensi Responden Kualitas Hidup Pasien TuberkulosisParu Di Rumah Sakit Paru Provinsi Sumatera Selatan

\begin{tabular}{lcc}
\hline Kualitas Hidup & $\begin{array}{c}\text { Frekuensi } \\
(\mathbf{n})\end{array}$ & $\begin{array}{c}\text { Persentase } \\
(\boldsymbol{\%})\end{array}$ \\
\hline Baik & 18 & 58,1 \\
Kurang Baik & 13 & 41,9 \\
\hline \multicolumn{1}{c}{ Total } & 31 & 100,0 \\
\hline
\end{tabular}


Berdasarakan tabel 2 dapat diperoleh hasil bahwa responden kualitas hidup baik sebanyak 18 orang $(58,1 \%)>$ dibandingkan dengan responden yang memiliki kualitas hidup kurang baik sebanyak 13 orang $(41,9 \%)$.

\section{Analisa Bivariat}

Tabel 3

Hubungan Pengetahuan Tentang Tuberkulosis Paru Dengan Kualitas Hidup Pasien

Tuberkulosis Paru Di Rumah Sakit Khusus Paru Provinsi Sumatera Selatan

\begin{tabular}{|c|c|c|c|c|c|c|c|}
\hline \multirow{4}{*}{$\begin{array}{c}\text { Tingkat } \\
\text { Pengetah } \\
\text { uan }\end{array}$} & \multicolumn{4}{|c|}{ Kualitas Hidup } & \multirow{2}{*}{\multicolumn{2}{|c|}{ Jumlah }} & \multirow{4}{*}{$\begin{array}{c}\mathbf{P} \\
\text { Value }\end{array}$} \\
\hline & & & & & & & \\
\hline & \multicolumn{2}{|c|}{ Baik } & \multicolumn{2}{|c|}{$\begin{array}{c}\text { Kurang } \\
\text { Baik }\end{array}$} & & & \\
\hline & n & $\%$ & n & $\%$ & n & $\%$ & \\
\hline Baik & 11 & & 0 & $0 \Omega$ & 41 & & \\
\hline Kurang & 4 & 23,5 & 13 & 76,5 & 17 & 100,0 & \\
\hline Total & 18 & & 13 & & 31 & 100,0 & \\
\hline
\end{tabular}

Pada tabel 3 dapat terlihat bahwa dapat diketahui bahwa dari 31 orang responden didapatkan dari total 14 orang responden dengan kategori pengetahuan baik yaitu yang memiliki kualitas hidup dengan kategori baik yaitu 14 responden $(100,0 \%)$, tidak ada responden yang memiliki kualitas hidup kurang baik. Dari total 17 orang responden dengan kategori pengetahuan kurang yaitu yang memiliki kualitas hidup dengan kategori baik 4 orang $(23,5 \%)$, memiliki kualitas hidup dengan kategori kurang baik yaitu 13 orang $(76,5 \%)$.

Analisa hubungan antara tingkat pengetahuan dengan kualitas hidup pada pasien tuberkulosis dilakukan dengan menggunakan uji Chi-Square dengan taraf signifikan $\alpha=0,05$ dengan $p$ value $=0,000$ $\leq \alpha=0.05$, sehingga $\mathrm{H} 0$ ditolak dan $\mathrm{Ha}$ diterima dapat disimpulkan bahwa ada hubungan tingkat pengetahuan tentang tuberkulosis dengan kualitas hidup pasien tuberkulosis paru di Rumah Sakit Khusus Paru Provinsi Sumatera Selatan.

\section{PEMBAHASAN \\ Analisis Univariat \\ A. Pengetahuan}

Berdasarkan data yang diperoleh dari 31 responden didapatkan hasil bahwa responden dengan Tingkat pengetahuan baik sebanyak 14 orang $(45,2 \%)<$ dibandingkan dengan responden yang memiliki tingkat pengetahuan kurang sebanyak 17 orang $(54,8 \%)$.

Pengetahuan merupakan hasil pengindraan manusia atau hasil seseorang terhadap objek melalui indra yang di memilikinya (mata, hidung, telinga, dan sebagainya). Pengetahuan atau kognitif merupakan domain yang sangat penting untuk terbentuknya tindakan seseorang (over behavior). (Notoadmodjo, 2010) Pengetahuan yang baik dalam penelitian ini adalah wawasan atau pemahaman yang dimiliki responden tentang penyakit tuberkulosis paru yang mencakup pengertian, tanda dan gejala. Budiman (2013) menjelaskan tentang faktor yang dapat mempengaruhi pengetahuan yaitu pendidikan, informasi/media massa, social, budaya, lingkungan dan ekonomi, usia.

Penelitian yang dilakukan Ariyani (2016) bahwa sebagian besar responden yakni $42,50 \%$ memiliki pengetahuan cukup mengenai penyakit, penularan penyakit dan pengobatan TB paru. Akan tetapi proporsi responden yang berpengetahuan kurang masih lebih tinggi yakni sebesar 35\% dibandingkan proporsi responden yang berpengetahuan baik yakni hanya $20 \%$.

Menurut asumsi peneliti berdasarkan hasil penelitian yang telah dilakukan kepada 31 responden didapatkan data yang tertinggi dengan tingkat pengetahuan kurang sebanyak 17 responden. Hasil penelitian ini juga menunjukkan ada 14 responden dengan tingkat pengetahuan baik. Kurangnya pengetahuan responden dikarenakan kurangnya pemahaman tentang penyakit tuberkulosis serta jarangnya responden mengikuti kegiatan 
pendidikan kesehatan yang diadakan oleh Rumah Sakit Khusus Paru Provinsi Sumatera Selatan, kurangnya informasi yang didapat dari pendidikan baik formal maupun non formal menyebabkan kurangnya mendapat informasi mengenai bakteri tuberkulosis dan cara pencegahannya.

\section{B. Kualitas Hidup}

Berdasarkan data yang diperoleh dari 31 responden yang mengalami kualitas hidup baik sebanyak 18 orang $(58,1 \%)>$ dibandingkan dengan responden yang memiliki kualitas hidup kurang baik sebanyak 13 orang $(41,9 \%)$.

Kualitas hidup merupakan keadaan dimana seseorang mendapatkan kepuasan atau menikmati dalam kehidupan seharihari. Kualitas hidup tersebut menyangkut kesehatan fisik dan menta, hubungan sosial serta hubungan individu dengan lingkungan maka orang tersebut akan mencapai suatu kepuasan dalam hidupnya. (Pariyana, 2018)

Hal ini sejalan dengan penelitian Jasmiati (2017) berdasarkan hasil penelitian yang dilakukan terhadap 41 responden didapatkan hasil bahwa sebagian besar kualitas hidup baik sebanyak 21 orang responden $(51,2 \%)$. Hal ini menunjukkan bahwa hampir sama antara dukungan keluarga rendah dan kualitas hidup baik. Hasil analisis OR $(6,000)$ yang artinya pasien dengan dukungan keluarga tinggi 6,000 kali memiliki kualitas hidup yang baik dibandingkan pasien yang dukungan keluarga rendah.

$$
\text { Menurut asumsi penelitian }
$$

berdasarkan hasil penelitian yang telah dilakukan kepada 31 responden,didapatkan yang terbanyak yaitu 16 orang dalam kualitas hidup baik hal ini berkaitan dengan semakin tinggi tingkat pengetahuan responden tentang tuberkulosis semakin baik kualitas hidupnya. Kualitas hidup merupakan suatu persepsi individu terhadap kondisi kesehatan fisik, kesehatan psikologis, hubungan sosial, lingkungan.

$$
\text { Hasil penelitian ini juga }
$$
menunjukkan ada 18 orang dalam kategori kualitas hidup baik dan 13 orang dalam kategori kualitas hidup kurang baik. Responden yang mengalami kualiatas hidup baik berkaitan dengan dukungan yang didapatkan dari keluarga dan lingkungan serta adanya motivasi dalam diri untuk sembuh, patuh dalam program pengobatan sehingga kesehatan semakin membaik sedangkan responden yang mengalami kualitas hidup buruk berkaitan dengan kurangnya dukungan yang didapatkan seperti motivasi dan dalam mengunjungi pelayanan kesehatan sehingga responden ada yang masih merasakan efek dari penyakit tuberculosis yang menggangu aktivitas sehari-hari.

Analisa Bivariat

$\begin{array}{llr}\text { Hubungan } & \text { Pengetahuan } & \text { Tentang } \\ \text { Tuberkulosis } & \text { Paru Dengan } & \text { Kualitas } \\ \text { Hidup Pasien } & \text { Tuberkulosis } & \text { Paru Di } \\ \text { Rumah Sakit Khusus Paru } & \text { Provinsi } \\ \text { Sumatera Selatan } & & \end{array}$

Hasil uji statistik dapat diketahui bahwa dari 31 orang responden didapatkan dari total 14 orang responden dengan kategori pengetahuan baik yaitu yang memiliki kualitas hidup dengan kategori baik yaitu 14 responden $(100,0 \%)$, tidak ada responden yang memiliki kualitas hidup kurang baik. Dari total 17 orang responden dengan kategori pengetahuan kurang yaitu yang memiliki kualitas hidup dengan kategori baik 4 orang $(23,5 \%)$, memiliki kualitas hidup dengan kategori kurang baik yaitu 13 orang $(76,5 \%)$.

Menurut asumsi peneliti,Responden yang memiliki pengetahuan yang baik, informasi cukup, motivasi dan dukungan dari orang terdekat,serta mtoivasi untuk sembuh berkaitan dengan kualitas hidup yang baik, sedangkan pada responden yang memiliki kualitas hidup buruk berkaitan dengan kurangnya informasi/pengetahuan kesehatan yang didapat serta dukungan yang didapat dari keluarga dan lingkungan sosial yang kurang.

Analisa hubungan antara pengetahuan dengan kualitas hidup pada pasien tuberkulosis paru dilakukan dengan 
menggunakan uji Chi-Square dengan taraf signifikan $\alpha=0.05$ dengan $p$ value $=0.000$ $<\alpha=0.05$, sehingga $\mathrm{H} 0$ ditolak dan $\mathrm{Ha}$ diterima dapat disimpulkan bahwa ada hubungan pengetahuan tentang tuberkulosis paru dengan kualitas hidup pasien tuberkulosis paru di Rumah Sakit Khusus Paru Provinsi Sumatera Selatan.

Penelitian yang dilakukan oleh Ariyani (2016) hubungan tingkat pengetahuan dengan kepatuhan pada pengobatan penderita tuberkulosis paru di Puskesmas Pekauman Kota Banjarmasin, Kalimantan Selatan. Berdasarkan tabel correlation diperoleh informasi nilai korelasi spearman's antara pengetahuan dan kepatuhan pasien sebesar 0,383. Itu berarti ada korelasi lemah dan searah, atau dengan kata lain jika pengetahuan responden bagus maka kepatuhan pasien terhadap pengobatan juga bagus, begitu juga sebaliknya. Tingkat signifikansi $(0=0,000)<(\alpha / 2)$ maka H0 ditolak, yang bearti ada hubungan yang signifikan dengan taraf nyata kurang dari 0,05 .

Penelitian yang dilakukan Nurfadillah (2014) yaitu kategori pengetahuan tentang Tuberkulosis Paru dan tindakan pencegahan penularan Tuberkulosis Paru pada keluiarga penderita Tuberkulosis Paru di RSUD Arifin Achmad Provinsi Riau, maka untuk mengetahui hubungan pengetahuan dengan tindakan pencegahan penularan Tuberkulosis Paru, kedua data tersebut diuji menggunakan analisa statistik Chi square atau Fisher jika syarat uji Chi square tidak terpenuhi (jumlah sel dengan nilai expectednya kurang dari $5>20 \%$.Setelah dilakukan perhitungan statistik didapatkan nilai signifikansi $p=0,04$ maka dapat diambil kesimpulan bahwa ada hubungan antara pengetahuan tentang TB Paru dengan tindakan pencegahan penularan TB Paru.

Peneliti berasumsi bahwa kualitas hidup pada penderita tuberculosis dipengaruhi oleh tingkat pengetahuan yang dimiliki, melalui pengetahuan yang baik membuat penderita memahami tentang kesehatan dan dengan kesadaran diri yang baik untuk dapat mengikuti program pengobatan dengan baik sehingga dapat meningkatkan kualitas hidup pasien itu sendiri.

\section{KESIMPULAN}

Berdasarkan hasil penelitian maka diperoleh kesimpulan sebagai berikut :

1. Diketahui bahwa dari 31 responden didapatkan Tingkat pengetahuan baik sebanyak 14 orang $(45,2 \%)<$ dibandingkan dengan responden yang memiliki tingkat pengetahuan kurang sebanyak 17 orang $(54,8 \%)$.

2. Diketahui bahwa dari 31 responden diperoleh hasil bahwa yang mengalami kualitas hidup baik sebanyak 18 orang $(58,1 \%) \quad>$ dibandingkan dengan responden yang memiliki kualitas hidup kurang baik sebanyak 13 orang $(41,9 \%)$.

3. Ada Hubungan pengetahuan tentang tuberkulosis paru dengan kualitas hidup pasien tuberkulosis paru di Rumah Sakit Khusus Paru Provinsi Sumatera Selatan, didapatkan $p$ value $=0,000 \leq \alpha=0.05$, sehingga $\mathrm{H} 0$ ditolak dan Ha diterima.

\section{SARAN}

Dalam penelitian ini ada beberapa saran yang dapat disampaikan yang kiranya bermanfaaat yaitu sebagai berikut:

\section{Bagi Institusi dan Pendidik Keperawatan}

Penelitian ini dapat dijadikan sebagai bahan referensi bagi yang tertarik pada penelitian tuberkulosis maupun kualitas hidup dan memberikan masukan untuk mengembangkan keilmuan dalam keperawatan medikal bedah tentang hubungan pengetahuan tentang tuberkulosis paru dengan kualitas hidup pasien tuberkulosis paru. 


\section{Bagi Rumah Sakit Khusus Paru Provinsi Sumatera Selatan}

a.Penelitian ini diharapkan bermanfaat bagi pihak rumah sakit sebagai referensi dan evaluasi dalam meningkatkan kualitas hidup penderita tuberkulosis

b.Diharapkan dapat menjadi upaya bagi pihak rumah sakit sebagai pemberian penyuluhan dan konseling guna membantu melaksanakan upaya preventif terhadap kejadian tuberkulosis paru

\section{Bagi peneliti}

Keterbatasan waktu penelitian maka perlu adanya penelitian yang lebih mendalam lagi mengenai faktorfaktor yang mempengaruhi kualitas hidup pasien tuberkulosis paru.

\section{DAFTAR PUSTAKA}

Adinda. (2018). Hubungan Antara Tingkat Pengetahuan Tentang Tuberkulosis di Wilayah Kerja Puskesmas Lempake Samarinda.Universitas Muhamadiyah. Kalimantan Timur

Amin, Zulkifli, dkk. (2007). Buku Ajar Ilmu Penyakit Dalam. Jilid II.Edisi IV.Jakarta:FKUI

Angriyani, D. (2008). Kualitas Hidup pada Orang dengan Penyakit Lupus Erythematotus (Odapus).Skripsi Fakultas Psikologi Universitas Airlangga

Ardiansyah, M. (2012). Medikal Bedah Untuk Mahasiswa. Jogjakarta: Diva Press

Arifah. (2015). Gambaran kualitas hidup pada pasien tuberculosis paru di puskesmas pada suka Kecamatan Cibeunying Kidul Kota Bandung. Universitas Pendidikan Indonesia
Ariyani. (2016). Hubungan Tingkat Pengetahuan Dengan Kepatuhan Pada Pengobatan Penderita Tuberkulosis Paru Di Puskesmas Pekauman Kota Banjarmasin, Kalimantan Selatan.

Budiman \& Riyanto A. (2013). Kapita Selekta Kuisioner Pengetahuan Dan Sikap Dalam Penelitian Kesehatan. Jakarta :SalembaMedika pp 66-69

Budiman, dan Riyanto Agus.(2013). Pengetahuan dan Sikap Dalam Penelitian Kesehatan. Jakarta: Salemba Medika

Departemen Kesehatan Republik Indonesia. (2011). Program Penanggulangan Tuberkulosis. Jakarta: Departemen Kesehatan RI.

Depkes RI. (2009). BukuSaku Program Penanggulangan TB.Departemen Kesehatan Republik Indonesia; Ditjen P2PL.

Diana.(2014). Hubungan Pengetahuan Dan Sikap Dengan Kepatuhan Berbat Pada Pasien TB Paru Yang Rawat Jalan Di Jakarta Tahun 2014.

Dinas Kesehatan Kota Palembang. Profil Kesehatan Tahun 2018. Palembang

Dinas Kesehatan Provinsi Sumatera Selatan. Profil Kesehatan Tahun 2018. Palembang

Gonzalez, B. (2012). Fector associated with health related quality of life in adults with astma. Multidisciplinary resppiratory medicine, 7 (1), 32 http://doi.org/10.1186/2049-69587-32 diakses April 2019

Ida. (2014). Hubungan Pengetahuan dan Sikap dengan Kepatuhan Berobat 
pada Pasien TB Paru yang Rawat Jalan di Jakarta Tahun 2014

Jasmiati. (2017). Hubungan Dukungan Keluarga Dengan Kualitas Hidup Pada Pasien TB Paru.

Kemenkes RI. (2010). Riskesdas 2010 Badan Penelitian dan Pengembangan Kesehatan Kementerian Kesehatan RI. Jakarta

Kemenkes RI. (2013). Profil Kesehatan Indonesia 2013. Jakarta: Kemenkes RI.

Kementerian Kesehatan. (2012).Pedoman Penanggulangan Infeksi Saluran Pernafasan Akut. : Jakarta

Kementerian Kesehatan. (2016).Pedoman Penanggulangan Infeksi Saluran Pernafasan Akut. : Jakarta

Kurniawan.(2008). Gambaran Kualitas Hidup penderita diabetes Mellitus.Universitas Padjadjaran. Bandung

Miranti. (2012). Faktor - Faktor Yang Memperngaruhi Kualitas Hidup Penderita TB Paru

Mita, P. (2011). Hubungan Pengetahuan Dan Sikap Penderita TB Paru Dengan Kepatuhan Minum Obat Anti Tuberkulosis di Puskesmas Lindah kulon Surabaya

Mubarak, W. I. (2011).Promosi Kesehatan untuk Kebidanan. Jakarta: Salemba medika

Naga, S.S. (2012). Buku Panduan Lengkap Ilmu Penyakit Dalam. Jogjakarta: DIVA Press.

Notoatmodjo, (2010).Metode Penelitian Kesehatan. Jakarta: Rineka Cipta.
Notoatmodjo, S. (2010).Ilmu Perilaku Kesehatan. Jakarta: Rineka Cipta

Notoatmodjo, S. (2012).Metodologi Penelitian Kesehatan. Jakarta : Rineka Cipta

Nurfadillah. (2014). Hubungan Pengetahuan Dengan Tindakan Pencegahan Penularan pada Keluarga Penderita Tuberkulosis Paru Di Ruang Rawat Inap Paru RSUD Arifin Achmad Provinsi Riau.

Nursalam. (2008) .Konsep dan penerapan metodologi penelitian keperawatan. Edisi 2.Jakarta : Salemba Medika

Pariyana. (2018). Perbedaan Perkembangan Kualitas Hidup Penderita TB Paru Menggunakan Instrumen Indonesiawhoqolbreffquestionare Terhadap Fasse Pengobatan Tuberculosis.

PPTI (Perkumpulan Pemberantasan Tuberkulosis Indonesia), (2010).Buku Saku PPTI. Jakarta, Website: www.ppti.info.

PPTI. (2012). PerkumpulanPemberantasanTuberk ulosis Indonesia, volume 8 : Jakarta

Prasetyo. (2007). MPKT MODUL 1. Jakarta: LembagaPenerbitan FEUI.

Riyanto, Agus, (2011). Aplikasi Metodologi Penelitian Kesehatan. Nuha.Medika Yogyakarta

Sarafino, E. P., (2011). Health psychology: Biopsychosocial interactions United States of America : John Willey \& Sons Inc

Saraswati,dkk. (2016) Pravelensi Diabetes Melitus dan TB Paru Semarang. 
jurnal Kesehatan Masyarakat : Semarang

Sugiyono. (2009). Metode penelitian kuantitatif kualitatif dan $R \& D$. Bandung :Alfabeta

Sugiyono. (2011). Metode penelitian kuantitatif kualitatif dan $R \& D$. Bandung :Alfabeta

Sugiyono. (2015). Metode Penelitian Pendidikan Pendekatan Kuantitatif, Kualitatif Dan R\&D. Bandung: Alfabeta.

Sugiyono. (2016). Metode Penelitian Pendidikan Pendekatan Kuantitatif, Kualitatif Dan R\&D. Bandung: Alfabeta.

Suryo J (2010). Herbal penyembuh gangguan sistem pernafasan. Edisi pertama. Yogyakarta: B First (PT Bentang Pustaka).

Sylvia A. Price. (2016). Aplikasi Nanda Nic Noc. Penerbit : Mediaction

Ulfah. (2012) .Pengaruh Dukungan Keluarga terhadap Kualitas Hidup Pasien Diabetes Mellitus Tipe 2.Jurnal Keperawatan. Bandung Universitas Padjajaran.

WHO (2015). Global tuberkulosis report http://www.who.int/tb/publications / global_report/en/,Diakases April 2019.

Wijaya, A.S. (2013). Keperawatan medical bedah 2. Keperawatan dewasa teori dan contoh askep. Yogyakarta : Nuha medika

Yusran. (2016). Analisis Faktor Yang Mempengaruhi Kualitas Hidup Thalasemia Beta mayor. 
